\title{
Obturator Internus Muscle
}

National Cancer Institute

\section{Source}

National Cancer Institute. Obturator Internus Muscle. NCI Thesaurus. Code C33192.

A striated muscle covering the majority of the lateral wall of the pelvis, with its orig in on the ischiopubic ramus and obturator membrane and insertion on the greater trochanter, which functions to externally rotate the hip. 